\title{
Augmented Reality for Introduction of Unit Systems in Personal Computer
}

\author{
V. R. Palilingan, G. C. Rorimpandey, I. I. Kapoh \\ Pendidikan Teknologi Informasi dan Komunikasi Fakultas Teknik Universitas Negeri Manado \\ Tondano-Minahasa, Indonesia \\ gladlycrorimpandey@unima.ac.id
}

\begin{abstract}
There are lot of technologies that used to developing a learning media. Creative and attractive are some of reasons the teachers want to develop a learning media. Technology Augmented Reality is the one of user interface technology. It is not just attractive and creative, but it is also can reducing the cost for purchasing a practical tool. Introduction of unit system in personal computer is the part of computer assembly subject. So, aim of this research is to develop the learning media with augmented reality for introduction of unit system in personal computer. This research used multimedia development life cycle (MDLC). An analysis is done to determine the user and system requirements so that a list of requirements for the new system may derive. The learning media has main feature that will show the object visualization in augmented reality. Other feature is visualization object in 2 Dimension. The learning media is then tested to ensure that all functionalities provided are running well. Finally a conclusion is made that the learning media has accomplished the project purposes and fulfilled the requirements.
\end{abstract}

Keywords-Augmented Reality; Unit Systems; Personal Computer; $M D L C$

\section{INTRODUCTION}

The increasing of science and technology is the one thing that helps the development of technology in learning process. The influence of these developments is evident in effort to reform the education system and learning includes the learning media. The development of sophisticated technology and phenomenal turns affects not only the physical infrastructure or learning media, but also means of intangible such as the development of quality education personel or teacher who have the knowledge, ability, and skill to use the media. Indirectly, teachers are required to have innovative and ability to collaborate learning process with technology.

Technology computer related to computer interface devices (Human Computer Interface) is currently progressing very quickly. Along with the development of technology hardware display controller, this can be used to convey information in visual form. Media visualization can be developed to attract the interest of learning by displaying animated replica of augmented reality-based information. The learning process of assembling computer considered very necessary to used augmented reality technology as the learning media. This technology can introduce the component of unit systems in real view without spending much money to buy the real things of those components. The use of augmented reality technology in learning media also can facilitate students to be easier in understanding the material because it is supplied more interesting by 3 -dimensional image and animation.

So, the aim of this research was to design and build a learning media of introducing Unit Systems with augmented reality which is interactive, communicative and educative.

\section{Augmented REALITY (AR)}

\section{A. The Invention of Augmented Reality}

Virtual reality technology was started from 1957 to 1962 by Morton Heilig. He has created a simulator called Sensorama. In 1966, Ivan Sutherland was invented head-mounted display that he claimed as a window to the virtual world. In 1975, Myron Krueger found Videoplace which enable user can be interacted with virtual object for the first time. In 1989, Jaron Lanier introduced Virtual Reality and created commercial bussines in cyberspace. Then in 1992, Boeing researcher named Thomas Caudell was coined the term augmented reality in reference to a head-mounted display Boeing used to guide workers as they put together elctrical wiring harnesses for aircraft equipment. But in the same year, LB Rosenberg also developed one of Augmented Reality function called Virtual Fixtures. It used in AS Amstrong Air Force laboratory. Moreover, in that year, Steven Feiner, Blair, Maclntyre and Dorèe Seligmann introduced the major paper for develop prototype of Augmented Reality. After that year, the development of augmented reality was begun to grow.

\section{B. Definition of Augmented Reality}

Augmented reality is the integration of digital information with live video or the user's environment in real time. It hase elements are augmented by computer-generated sensory input such as sound, video, graphics or GPS data. Ronald T. Azuma in 1997 defined the augmented reality as the incorporation of real objects and virtual in a real environment, run interactively in realtime, and there is integration between objects in 3 Dimensions, namely integrated virtual objects in the real world. 


\section{UNIT SYSTEMS IN PERSONAL COMPUTER}

Unit system in personal computer is known as Central Processing Unit. It is computer hardware which used to accept, do command and manage data from software. The important parts of CPU are Control Unit, Arithmetic Logic Unit and Memory Unit. The ways of working of Central Procesing Unit are:

a) When data or instruction entered in processing-devices, firstly, it placed in Random Access Memory (RAM).

b) If it is instruction, stored by the control unit in the program storage, but if data, will be stored in working storage.

c) If the register is ready to accept the execution, then the control unit will take instructions from programstorage for stored to instruction register, while the memory address containing the instruction stored in the program counter.

d) While the data taken by the control unit of working storage to be accomodated in general purpose register

e) If the workmanship performed by instructions is arithmatic and logic, the Aricthmetic Logic Unit (ALU) will take over the operation to do based on the instruction set. The results are stored in the accumulator.

f) If the results of the processing have been completed, then the control unit will take the results of the processing in the accumulator to be accomodated back to working storage.

g) If the overall construction has been completed, then the control unit will pick up the processing of working storage to be accomodated to the output storage

h) Then later on output storage, processing results will be displayed to the output devices.

In this research, there are four object unit systems that modeled with augmented reality, which are: Processor, Motherboard, RAM, and Harddrive. Each object will have 2 models from different type.

\section{RESEARCH METHOD}

\section{A. Reseach Design}

The reseach design is based on Multimedia Development Life Cycle by Luther in 1994. This methodology has 6 steps, they are: concept, design, obtaining content material, assembly, testing and distributing (see Fig. 1).

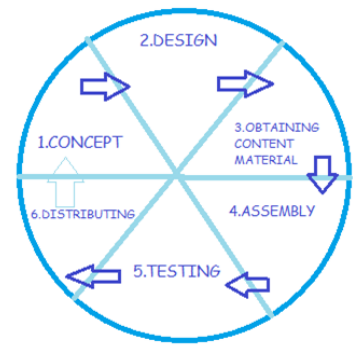

Fig. 1 Multimedia Development Life Cycle

1) Concept

This step is decided the aim and audiens of the application. The aim and audiens are giving impact to the multimedia design. The characteristic of the audiens should be considered in designing. Besides, this step decided the type of the application, it is for presentating, learning and so on.

2) Design

This step is designing the specification about application architecture, style, interface and materials need. The specification should be very clear so the next step, the new decision will not be taken. This step usualy used storyboard for drawning the description each scene.

3) Obtaining Content Material

This step is collecting materials as need to be work for. The materials include picture, clip art, photo, animation, audio, and so on. This step, reseacher used materials such as: processor model, ram model, hardisk drive model, motherboard model, animation software, augmented reality software.

4) Assembly

This step is built the all application based on the design step. All materials that used in this step are from the step 3 .

5) Testing

This step will not be discussed. But overall, this step will produce the testing module and how the result of the testing by developer expert and end-user expert.

6) Distributing

This step also will not be discussed. In this step, the application will distribute to the audiens.

\section{B. Technique of Collecting Data}

This research are using 2 techniques of collecting data, they are interview and obeservation. The interview has done with one target or topic with a view question and also done with a group of specific question to be asked. The obeservation has done with participative and non participative obeservation. In participative obsevartion, investigator become a part of the object.

\section{RESUlTS}

The results of this research is done based on Multimedia Development Life Cycle which has 4 steps from 6 steps as shown on Fig. 1 in Reseach Method section. They are: concept, design, obtaining content material, assembly, testing and distributing. The testing and distributing will not be discussed.

\section{A. Concept}

Concept of this media is devided into two parts, are: using single marker and using multi marker. Forms logic flow in the use of a single marker can be visualized in Fig. 2. In the single marker design process can be described as follows: Virtual Objects (3D) generated from the Blender 3D rendering which is then stored on the computer, then perform the image capture device webcam markers which are stored on a computer for processing by using the 3D Openspace. And the final result that 
emerged is a combined form of Virtual Object Visualization (3D) with the external environment (marker).

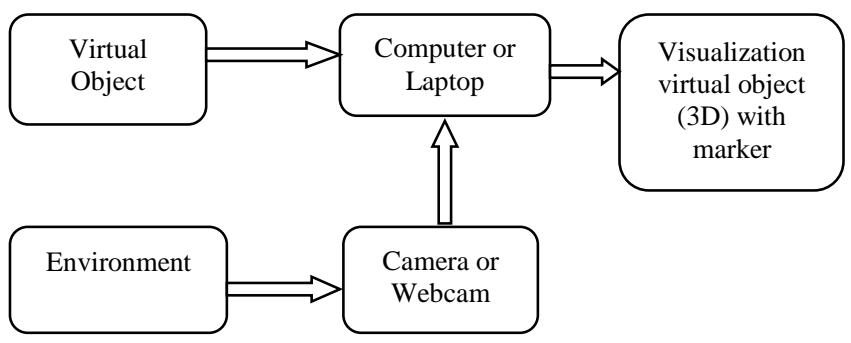

Fig. 2 Using Single Marker

Forms logic flow in the use of multi markers (see Fig. 3) can be visualized on the draft marker single process can be described as follows: some objects Virtual (3D) resulting from the rendering device blender $3 \mathrm{D}$ which is then stored on the computer, then the webcam perform image capture markers that more than one kind markers which are stored on a computer for processing by using the 3D Openspace. And the final result that emerged is a combined form of some object Virtual Visualization (3D) with the external environment (marker).

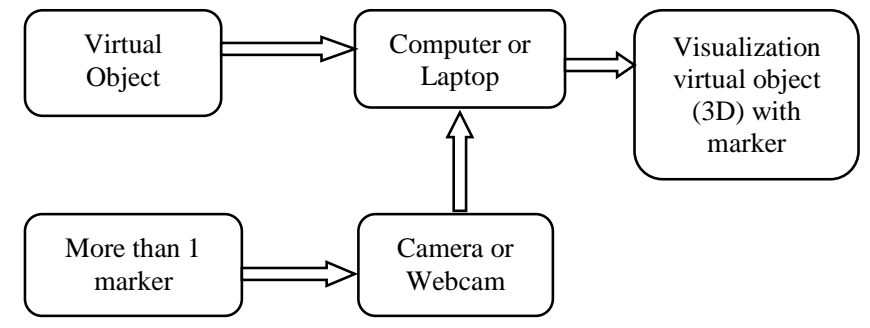

Fig. 3 Using Multi marker

\section{B. Design}

This step has given results of design interface that will be interacted with the user. Interface for the main menu of this learning media is shown at Fig. 4 below:

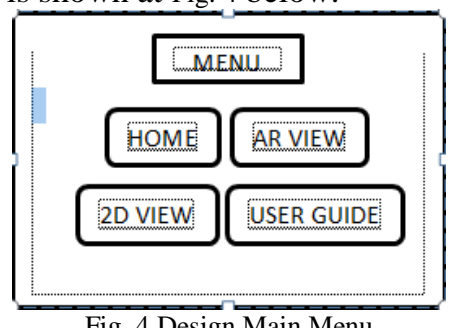

Element text will be used are BankGothic Lt BT and Stencil then in the buton and background will be animated. Inteface design for AR View is shown in Fig. 5 below:

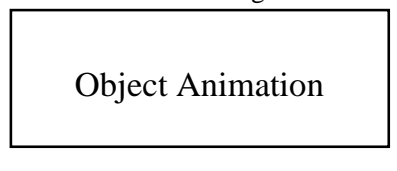

Fig. 5 Design Page of AR View

\section{Obtaining Content Material}

At this stage all the materials collected in accordance with needs done. These materials are a clip art image, photo or image, animation, 3D objects, and others. In this phase, researchers took from the Internet materials in the form of clip art and photo / image either to be used as background and menu buttons, whereas for application interfaces researcher using Adobe Flash CS6 and for 3D objects together with animation made by researchers using the application Blender 3D and Openspace 3D. The objects that are created are:

1) Object Processor Intel i7, which has type 3D animation, texture file intel core i7.jpg, using cube object, type of export is .obj, dimensions $\mathrm{x}(4.665)$ $y(1.175) z(9.885)$, size of dimension 5.100 and marker 2.080 useful for scale.

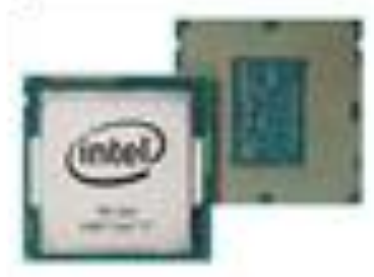

Fig. 6 Model of Intel i7 Processor

2) Object AMD Sempron Processor, which has type 3D animation, texture file AMD sepron.jpg, using cube object, type of export is .obj, dimensions $\mathrm{x}(9.429)$ $\mathrm{y}(0.873) \mathrm{z}(9.429)$, size 5.000 and marker 2.080 useful for scale.

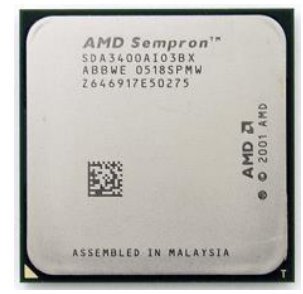

Fig. 7 Model of AMD Sempron Processor

3) Object of nvidia SLI RAM, which has 3D animation, texture file nvidia SLI.jpg, use cube object, export.bj, dimensions $\mathrm{x}(0.417) \mathrm{y}(18.490) \mathrm{z}(4.175)$, size of dimension 12.600 and marker size 2.080 useful for scale.

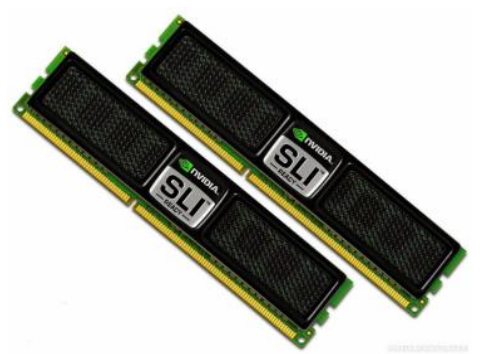

Fig. 8 Model of nvidia RAM

4) Object of Kingston RAM, which has $3 \mathrm{D}$ animation, texture file kingston.jpg, use cube object, export.bj, dimensions $\mathrm{x}(22.898) \mathrm{y}(0.497) \mathrm{z}(4.957)$, size of dimension 13.000 and marker size 2.080 useful for scale. 


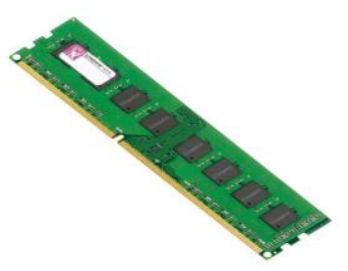

Fig. 9 Model of Kingston RAM

5) Object of SATA and ATA harddisk, which has 3D animation, texture file Sata and Ata.jpg, use cube object, export.bj, dimensions $\mathrm{x}(2.898) \quad \mathrm{y}(1.497)$ $z(4.057)$, size of dimension 6.000 and marker size 5.080 useful for scale.

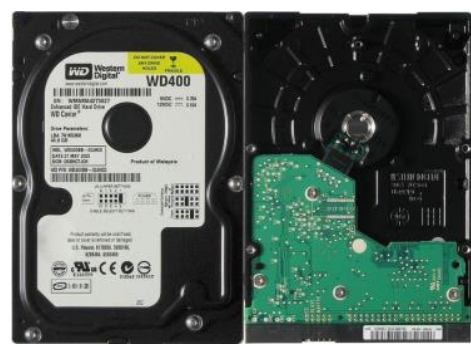

Fig. 10 Model of Sata and Ata Hardisk drive

6) Object of MSI motherboard, which has 3D animation, texture file Model Motherboard MSI.jpg, use cube object, export.bj, dimensions $\mathrm{x}(25.321) \mathrm{y}(3.555)$ $\mathrm{z}(20.627)$, size of dimension 13.200 and marker size 4.000 useful for scale.

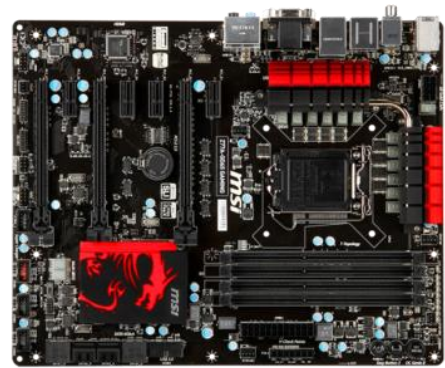

Fig. 11 Model of MSI Motherboard

7) Object of Gigabyte motherboard, which has 3D animation, texture file Model Gigabyte.jpg, use cube object, export.bj, dimensions $\mathrm{x}(13.089) \mathrm{y}(0.018)$ $\mathrm{z}(10.198)$, size of dimension 13.300 and marker size 3.880 useful for scale.

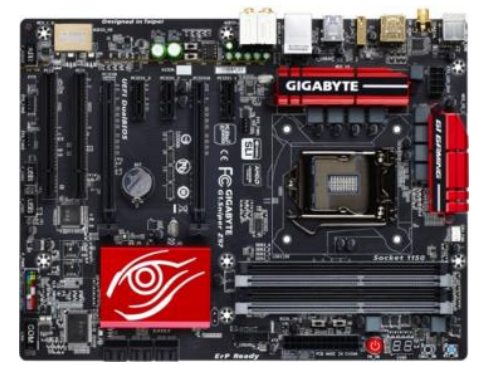

Fig. 12 Model of Gigabyte Motherboard

\section{Assembly}

The hardware were using in modeling an augmented reality have specification as follow:Intel Core i7-3217U $2.80 \mathrm{GHz}$, 4GB DDR3 PC-12800 Memory, VGA NVIDIA GeForce GT 720 M graphic 2Gb, 14.0" WXGA, HD Color Shine LED 1366 x 768 pixel and ebcam External B-PRO $514 \mathrm{Mp}$. Whereas, the softwares were used are: Windows 8 Pro as operating system, Blender 3D 2.72, Adobe Flash CS6, Adobe Photoshop CC and Openspace 3D.

The steps of modeling an augmented reality object are:

1) Create object model with Blender

2) Right click in Cube, then press $S$ button for zoom in the cube

3) Choose cube then press $S$ and $X$ button for zoom out 2 edge of cube

4) Next, go to Edit Mode with press TAB button

5) Marked for create each of edge in object with press the Cltr-R button

6) Choose icon Face Select then mark each part of cube that will be modeled (press $\mathrm{C}$ button).

7) Press E button for create object so the object come into sight, if want more then press $\mathrm{S}$ button

8) Exit from Edit mode with $\mathrm{TAB}$ button and press $\mathrm{Z}$ button for see the line of built object.

9) For Texturing, choose Texture icon then Image or Move and choose UV.

10) Activate Material icon for help Texture.

11) Mark all part that will be textured, open new window then set to UV/Image editor.

12) Choose photo/image file and press $U$ button and choose Uvunwrp

13) When u have done, Export file into .obj.

14) Next step, open the openspace software and import the file .obj.

15) Make Object can be displayed by right click in Scane and choose Input Arcapture then click OK.

16) Right click in Scane and choose Input Armarker and choose file that will be displayed the OK.

17) Right click in Scane and choose Object Hide to choose file that will be displayed later.

18) Right click Armarker then choose Found.

19) Right Click Object hide and choose Show.

20) Right Click Object hide and choose Lost.

21) Right Click Object hide and choose Hide.

22) The last step, try to use marker 0 by press icon play.

\section{ACKNOWLEDGMENT}

Thanks to ICIEVE 2015 Committee that give us opportunity to publish our paper. Thanks to the Rector of Universitas Negeri Manado and the Dean of Engineering Faculty of Universitas Negeri Manado for giving us permission to submit and present our paper. Thanks to all the families of the researchers that always support while we are working on this paper. 


\section{REFERENCES}

[1] A Chowanda, Perancangan game kartu interaktif berbasis Android menggunakan Augmented Reality, 2nd ed., vol. 2. Jurnal ComTech: Jakarta, 2012, ISSN 20187-1244.

[2] Annastacia Novrianti Priyatna, Lisa Triana Putri, Mora Parlindungan, Tia Renita, "Implementasi Augmented Reality sebagai media pembelajaran pada simulasi terjadinya tsunami," Jakarta. Universitas Gunadarma, 2012, in press

[3] Heni A. Puspitosari, Belajar merakit Personal Computer (PC) sendiri. Yogyakarta, Indonesia: Skripta, 2013.

[4] Prof. Dr. Munir MIT, Multimedia konsep dan aplikasi dalam pendidikan. Bandung, Indonesia: Alfa Beta, 2012.

[5] Rusman, Belajar dan pembelajaran berbasis Komputer mengembangkan profesionalisme abad 21. Bandung, Indonesia: Alfa Beta, 2012.

[6] Rosa A.S, Shalahudin M, Rekayasa perangkat lunak terstruktur dan berorientasi objek. Bandung, Indonesia: Informatika Bandung, 2013.
[7] Eka Ardhianto, Wiwien Hadikurniawati, Edy Winarno, Augmented Reality objek 3 dimensi dengan perangkat Artoolkut dan Blender, 2nd Ed., Vol. 17. Semarang: Jurnal Teknologi Informasi, 2012, pp. 107-117.

[8] Daniela D'Auria, Dario Di Mauro, Davide Maria Calandra, Francesco Cutugno, A 3D Audio Augmented Reality System for a Cultural Heritage Management and Fruition, $4^{\text {th }} \mathrm{ed}$, vol.13. Journal of Digital Information Management. 2015. ISSN 0972-7272.

[9] Ettore Marzano, Tullio Piardi, Luc Soler, Michele Diana, Didier Mutter, Jacques Marescaux, Patrick Pessaux, Augmented Reality-Guided Artery-First Pancreatico-Duodenectomy, $11^{\text {th }}$ ed, vol. 17. Journal of Gastrointestinal Surgery: New York, 2013, ISSN 1091255X

[10] Bernd Resch, Andreas Wichmann, Nicolas Goell, Usability in 4D AR: Visualising Multi-temporal Real-time Geo-data in Augmented Reality Environments, $4^{\text {th }}$ ed, vol. 9. International Journal of Interactive Mobile Technologies, 2015. ISSN 1865-7923.

[11] M-Carmen Juan, Magdalena Mendez-Lopez, Elena Perez-Hernandez, Sergio Albiol-Perez, Augmented Reality for the Assessment of Children's Spatial Memory in Real Settings, $12^{\text {th }}$ ed, vol. 9. PloS One: San Francisco, 2014. 